\title{
PELAKSANAAN PERLINDUNGAN ANAK YANG TEREKSPLOITASI SECARA EKONOMI OLEH PEMERINTAH KOTA PADANG
}

\author{
Laurensius Arliman S. \\ email: laurensiusarliman@gmail.com
}

\begin{abstract}
Children are our future and in their own time bear the responsibility to develop their own world. To enable them doing so, they should not be forced to work to earn a living or support their family. Children should be allowed to grow in the safety of a home, at school and at playgrounds. In this paper the author will explore children problems related economic exploitations, what policies are developed by the municipal government of Padang to protect children from economic exploitations and what are the obstacles in implementing these policies. One of the finding is that the Social and Manpower Service and the Family Planning, Women and Community Empowerment Board of the Padang municipal government develops training programs aiming to give exploited children practical skills in helping them to cope. Factors influencing economic exploitation of children are numerous and complex: lack of education, lessening of people's adherence to religious norms, societal environment, shift in cultural values, economic problems, etc. Based on the above the author suggests that the municipal government should take cognizance of these factors when attempting to deal with the problem.
\end{abstract}

Keywords:

child, exploitation, economy, protection.

\begin{abstract}
Abstrak
Anak adalah generasi penerus bangsa yang suatu saat akan meneruskan kegiatan pembangunan. Anak tidak boleh menjadi tulang punggung ekonomi keluarga. Anak-anak hanya boleh berada di tiga tempat, yakni: rumah, sekolah dan tempat mereka bermain saja. Dalam makalah ini penulis mengangkat masalah anak yang mengalami eksploitasi secara ekonomi di kota Padang dan peran dari pemerintah Kota Padang terhadap perlindungan anak yang mengalami eksploitasi secara ekonomi, serta apa saja kendala dari Pemerintah Kota Padang dalam pemenuhan hak perlindungan anak tersebut. Perlindungan anak yang mengalami eksploitasi secara ekonomi, dilaksanakan oleh Dinas Sosial Dan Tenaga Kerja (Dinsosnaker) Padang dan Badan Pemberdayaan Masyarakat, Perempuan dan Keluarga Berencana (BPMPKB) Kota Padang. Kedua lembaga pemerintah ini membina anak-anak yang dieksploitasi secara ekonomi, dan memberikan kepada mereka pelatihan keterampilan. Dalam penelitian ditemukan sejumlah faktor yang menyebabkan tidak terpenuhinya pemenuhan hak perlindungan anak yang dieksploitasi secara ekonomi, antara lain, nilai agama yang luntur, pendidikan, lingkungan masyarakat, masalah ekonomi, pergeseran budaya. Berkaitan dengan itu pemerintah kota Padang harus memperhatikan kendala-kendala tersebut, agar pemenuhan perlindungan hak anak dapat terwujud dengan nyata.
\end{abstract}

Kata Kunci:

hak anak, eksploitasi, ekonomi, perlindungan. 


\section{Pendahuluan}

Anak adalah generasi penerus bangsa yang akan membawa perubahan pada pembangunan. Oleh karenanya, anak sejak dalam kandungan hingga usia 18 tahun, perlu mendapatkan haknya. Hak anak adalah hak asasi yang sifatnya melekat. Hal tersebut di atas sesuai dengan ketentuan Konvensi Hak Anak yang telah diratifikasi oleh pemerintah Indonesia melalui Keputusan Presiden Nomor 36 Tahun 1990 yang mengemukakan prinsip-prinsip umum perlindungan anak, yaitu non diskriminasi, kepentingan terbaik anak, kelangsungan hidup dan tumbuh kembang, dan menghargai pandangan anak. Dalam konteks kehidupan, prinsip tersebut dipergunakan untuk menjamin kelangsungan hidup dan perlindungan hukum dari negara. ${ }^{1}$ Senada dengan itu hak-hak anak merupakan bagian dari hak asasi manusia yang termuat dalam Pasal 28 B ayat (2) UndangUndang Dasar 1945 hasil amandemen kedua yang menyebutkan "setiap anak berhak atas kelangsungan hidup, tumbuh dan berkembang serta berhak atas perlindungan dari kekerasan dan diskriminasi. ${ }^{2}$

Dari sisi kehidupan berbangsa dan bernegara, anak adalah masa depan bangsa dan generasi penerus cita-cita bangsa, sehingga setiap anak berhak atas hak-hak yang termuat dalam Pasal 28 B ayat (2) yang telah dijelaskan di atas ${ }^{3}$. Pada kenyataannya, negara masih belum mampu memenuhi kewajibannya untuk melindungi hak-hak anak. Salah satu fenomena yang terjadi adalah keberadaan pekerja anak. Selain pekerja anak, fenomena sosial yang tidak bisa dibendung lagi adalah, banyaknya anak-anak yang menjadi pengamen atau pengemis di jalananjalanan ataupun di perempatan lampu merah. Tidak hanya melanggar hak-hak anak, bekerja juga membawa dampak buruk bagi anak-anak baik secara fisik maupun psikis. Bahkan dampak lebih jauh lagi, dengan bekerja dikhawatirkan

\footnotetext{
1 Wiwik Afifah, Pertanggungajawaban Pidana Anak Konflik Hukum, Jurnal Ilmu Hukum, Volume 10 Nomor 19, 48, 2014.

2 Iman Jauhari, Perbandingan Sistem Hukum Perlindungan Anak Antara Indonesia dan Malaysia, Jurnal Ilmu Syari'ah dan Hukum, Volume 57 Nomor 2, 612, 2013.

3 Nur Hidayati, Perlindungan Anak Terhadap Kejahatan Kekerasan Seksual (Pedofilia), Ragam Jurnal Pengembangan Humaniora, Volume 14 Nomor 1, 69, 2014.
} 
akan menganggu masa depan anak-anak untuk mendapatkan kehidupan yang lebih baik, terlebih anak-anak merupakan generasi penerus bangsa. ${ }^{4}$

Kota Padang sebagai pusat Ibukota dari Provinsi Sumatera Barat, wajib memenuhi aturan perlindungan hak-hak anak, agar kota Padang dapat menjadi contoh bagi kota-kota lainnya. Saat ini di kota Padang telah dikeluarkan peraturan daerah yang mengatur perlindungan terhadap anak yang tereksploitasi ekonomi. Peraturan daerah itu adalah Peraturan Daerah Kota Padang nomor 2 tahun 2012 tentang Pembinaan dan Perlindungan Anak. Dimana dalam Pasal 7 Peraturan Daerah tersebut, dinyatakan bahwa kewajiban dan tanggung jawab perlindungan anak adalah kewajiban dan tanggung jawab bersama: a) Pemerintah Daerah; b) masyarakat; c) keluarga dan orang tua; d) dunia usaha dan e) lembaga adat, media massa, keagamaan dan lembaga lainnya. Terhadap peran Pemerintah Daerah, Pasal 8 menjelaskan bahwa Pemerintah Daerah berkewajiban dan bertanggung jawab untuk: a) menghormati dan menjamin hak asasi anak tanpa membedakan suku, agama, ras, golongan, jenis kelamin, etnik, budaya dan bahasa, status hukum anak, urutan kelahiran anak, kondisi fisik dan mental anak; b) memberikan dukungan sarana dan prasarana dalam penyelengaraan pembinaan dan perlindungan anak; c) menjamin pembinaan dan perlindungan, pemeliharaan dan kesejahteraan anak dengan memperhatikan hak dan kewajiban orang tua, wali atau orang lain dan secara lingkungan bertanggung jawab terhadap anak; d) mengawasi penyelenggaraan perlindungan anak; e) menjamin anak untuk mempergunakan haknya dalam menyampaikan pendapat sesuai dengan usia dan tingkat kecerdasan anak. ${ }^{5}$

4 Astriani Rahman, Eksploitasi Orang Tua Terhadap Anak Dengan Mempekerjakan Sebagai Buruh, Jurnal Ilmu Hukum, Volume 8 Nomor 16, 2, (2013).

5 Sedangkan pasal yang khusus mengatur perlindungan anak tereksploitasi ekonomi terdapat di dalam Pasal 37 ayat (1) yang berbunyi Pemerintah Daerah, penegak hukum, LSM, atau organisasi sosial dan masyarakat berkewajiban dan bertanggung jawab memberi perlindungan bagi anak yang memerlukan perlindungan khusus dan ayat (2) menyebutkan perlindungan khusus sebagaimana dimana dimaksud ayat (1) diberikan pada anak dalam situasi darurat, anak yang berhadapan dengan hukum, anak dari kelompok minoritas dan terisolasi, anak yang dieksploitasi secara ekonomi dan/seksual, anak yang menjadi penyalahgunaan narkotika, alkohol, psikotropika dan zat adiktif lainnya (NAPZA), anak korban penculikan, penjualan, 
Wawancara penulis dengan salah seorang staf pemberdayaan perempuan Badan Pemberdayaan Masyarakat, Perempuan dan Keluarga Berencana (BPMPKB) kota Padang, yaitu Zulnimar, menyatakan tentang perkembangan sekarang di Kota Padang, yaitu masih banyak terdapat anak yang mengemis dan mengamen di lampu lalu lintas, masih banyaknya anak yang tidur di pasar dan tidak pulang ke rumahnya, masih banyak ditemukan anak-anak yang tidak bersekolah namun malah berkeliaran di pasar atau dijalanan kota Padang. ${ }^{6}$

\section{Tinjauan Perlindungan Anak}

Anak wajib dilindungi agar mereka tidak menjadi korban tindakan siapa saja (individu atau kelompok, organisasi swasta ataupun pemerintah) baik secara langsung maupun secara tidak langsung7 ${ }^{7}$ Yang dimaksud dengan korban adalah mereka yang menderita kerugian (mental, fisik, sosial), karena tindakan yang pasif, atau tindakan aktif orang lain atau kelompok (swasta atau pemerintah), baik langsung maupun tidak langsung. Pada hakikatnya anak tidak dapat melindungi diri sendiri dari berbagai macam tindakan yang menimbulkan kerugian mental, fisik, sosial dalam berbagai bidang kehidupan dan penghidupan. Anak harus dibantu oleh orang lain dalam melindungi dirinya, mengingat situasi dan

perdagangan, anak korban kekerasan fisik dan/mental, anak yang menyandang cacat dan anak korban pelakuan salah dan penelantaran. Sedangkan pada ayat (3) menjelaskan bahwa upayaya perlindungan khusus sebagaimana dimaksud pada ayat (2) adalah berupa pengawasan, perlindungan, perawatan, rehabilitas. Selanjutnya pada ayat (4) menjelaskan upaya sebagaimana dimaksud pada ayat (3) dilaksanakan oleh keluarga, LSM dan Pemerintah Daerah.

6 Zulnimar, Staf Badan Pemberdayaan Masyarakat, Perempuan dan Keluarga Berencana (BPMPKB) Kota Padang, wawancara dilakukan pada tanggal 20 September 2015, dimana selanjutnya Zulnimar menjelaskan bahwa Kota Padang melalui BPMPKB kota Padang dan Dinas Sosial kota Padang selalu mengaku kewalahan melakukan pembinaan terhadap anak yang tereksploitasi ekonomi yang telah terjaring razia, razia ini terjadi pada saat penertiban gepeng dan pengamen. Hal ini terjadi karena Kota Padang belum memiliki fasilitas yang memadai untuk menampug dan melatih anak yang terjadi razia, apalagi rumah panti sementara milik BPMPKB Kota Padang dan Dinas Sosial dan Tenaga Kerja kota Padang tidak cukup kapasitasnya, untuk menampung anak-anak jalanan dalam jumlah besar, hal ini akibat semakin bertambahnya jumlah anak jalanan dari tahun ke tahun di kota Padang.

7 Laurensius Arliman S, Komnas HAM dan Perlindungan Anak Pelaku Tindak Pidana, 11, Deepublish, Jogjakarta, 2015. 
kondisinya. Anak perlu mendapat perlindungan agar tidak mengalami kerugian, baik mental, fisik maupun sosial. ${ }^{8}$

Pelaksanaan Perlindungan Anak yang baik antara lain memenuhi beberapa persyaratan sebagai berikut: ${ }^{9}$

a. Para partisipan dalam terjadinya dan terlaksananya perlindungan anak harus mempunyai pengertian-pengertian yang tepat berkaitan dengan masalah perlindungan anak, agar dapat bersikap dan bertindak, secara tepat dalam menghadapi dan mengatasi permasalahan yang berkaitan dengan pelaksanaan perlindungan anak. Oleh sebab itu harus disebarluaskan, pengertian mengenai perlindungan anak, serta pengertian-pengertian lain yang dapat mendukung dilaksanakannya perlindungan anak tersebut.

b. Perlindungan anak harus dilakukan bersama antara setiap warga negara, anggota masyarakat secara individual maupun kolektif dan pemerintah demi kepentingan bersama, kepentingan nasional, mencapai aspirasi bangsa Indonesia. Dengan demikian pengadaan penyuluhan mengenai perlindungan anak adalah mutlak agar setiap warga negara dan anggota masyarakat sadar akan pentingnya perlindungan anak serta bersedia berpartisipasi secara aktif sesuai dengan kemampuan masing-masing;

c. Kerjasama dan koordinasi diperlukan dalam melancarkan kegiatan perlindungan anak yang rasional, bertanggung jawab dan bermanfaat antar partisipan yang bersangkutan. Perlu kita jauhkan, menghindari berbagai macam konfrontasi yang tidak perlu dan mengembangkan komunikasi yang positif, edukatif dan membangun (antar partisan) dalam pelaksanaan perlindungan anak;

d. Dalam rangka membuat kebijaksanaan dan rencana kerja yang dapat dilaksanakan perlu diusahakan inventarisasi faktor-faktor yang menghambat dan mendukung kegiatan perlindungan anak. Perlu diteliti masalah-masalah

8 Maidin Gultom, Perlindungan Hukum Terhadap Anak dan Perempuan, Refika Aditama, Bandung, 2012, hlm., 69.

9 Arif Gosita, Masalah Perlindungan Anak, PT Bhuana Ilmu Populer, Jakarta, 2004, hlm., 19-21. 
apa saja yang dapat merupakan faktor kriminogen atau faktor viktimogen dalam pelaksanaan perlindungan anak;

e. Dalam membuat ketentuan-ketentuan yang menyinggung dan mengatur perlindungan anak dalam berbagai peraturan perundang-undangan kita harus mengutamakan perspektif yang diatur dan bukan yang mengatur; mengutamakan perspektif yang dilindungi dan bukan persepektif yang dilindungi. Kepastian hukum perlu diusahakan demi kelangsungan kegiatan perlindungan anak dan untuk mencegah akibat-akibat yang tidak diinginkan.

f. Perlindungan anak harus tercermin dan diwujudkan atau dinyatakan dalam berbagai bidang kehidupan bernegara dan bermasyarakat. Dalam rangka melaksanakan perlindungan anak setiap anggota masyarakat dengan kerjasama dengan pemerintah, harus ikut serta menciptakan situasi dan kondisi yang memungkinkan dikembangkannya perlindungan anak, secara langsung atau tidak langsung dalam berbagai bidang kehidupan;

g. Dalam pelaksanaan kegiatan perlindungan anak, pihak anak harus diberikan kemampuan dan kesempatan untuk ikut serta melindungi diri sendiri dan di kelak kemudian hari dapat menjadi orangtua yang berpartisipasi positif dan aktif dalam kegiatan perlindungan anak yang merupakan hak dan kewajiban setiap anggota masyarakat;

h. Perlindungan anak yang baik harus mempunyai dasar-dasar filosofis, etis dan yuridis. Dasar tersebut merupakan pedoman pengkajian, evaluasi apakah ketentuan-ketentuan yang dibuat dan pelaksanaan yang direncanakan benarbenar rasional positif, dapat dipertanggungjawabkan dan bermanfaat bagi yang bersangkutan. Dasar-dasar ini dapat diambil dan dikembangkan dari Pancasila, Undang-Undang Dasar 1945, ajaran dan pandangan yang positif dari agama atau nilai sosial yang tradisional atau modern;

i. Pelaksanaan kegiatan perlindungan anak tidak boleh menimbulkan rasa tidak dilindungi pada yang bersangkutan, oleh karena adanya penderitaan, kerugian oleh partisipan tertentu. Perlindungan anak yang antara lain 
merupakan suatu kegiatan prevensi korban kejahatan jangan malahan menimbulkan korban. Perlindungan ini harus bersifat preventif; dan

j. Perlindungan anak harus didasarkan atas pengembangan hak dan kewajiban asasinya. Perlindungan anak di bidang kesehatan, pendidikan dan pembinaan/pembentukan kepribadian didasarkan pada hak asasi anak yang umum. Hak asasi umum untuk orang dewasa dalam hukum positif berlaku juga untuk anak (orang dewasa dan anak sama-sama manusia dan warga negara).

\section{Teori Perlindungan Khusus Anak}

Terhadap perkembangan perlindungan khusus anak, Wagiati Soetodjo berpendapat bahwa perlindungan khusus anak ini dimulai dari asas dua deklarasi hak-hak anak yang berbunyi, anak-anak mempunyai hak untuk memperoleh perlindungan khusus dan harus memperoleh kesempatan dan fasilitas yang dijamin oleh hukum dan sarana lain sehingga secara jasmani, mental akhlak, rohani, dan sosial, mereka dapat berkembang dengan sehat dan wajar dalam keadaan bebas dan bermanfaat. ${ }^{10}$

Sejalan dengan perlindungan khusus anak, H.R Abdussalam dengan berdasarkan Undang-Undang Hak Asasi Manusia dan Undang-Undang Perlindungan Anak menyatakan bahwa setiap anak berhak untuk memperoleh perlindungan khusus dari kegiatan eksploitasi ekonomi dan setiap pekerjaan yang membahayakan dirinya, sehingga dapat menganggu pendidikan, kesehatan fisik, moral, kehidupan sosial dan mental spiritualnya. Eksploitasi ekonomi maupun seksual ini misalnya tindakan atas perbuatan memperalat, memanfaatkan atau memeras anak untuk memperoleh keuntungan pribadi, keluarga atau golongan. ${ }^{11}$

10 Wagiati Soetodjo, Hukum Pidana Anak, 68-69, Refika Aditama, Bandung, 2006, hlm., 68-69.

11 H.R. Abdussalam, Hukum Perlindungan Anak, Restu Agung, Jakarta, 2007, hlm., 30-34. 


\section{Peran Pemerintah Kota Padang Dalam Memenuhi Perlindungan Anak}

Peran anak dalam aktivitas kehidupan sangat bervariasi, mulai dari rumah tangga atau keluarga sampai lingkungan yang lebih luas. Namun kenyataan menunjukkan keberadaan dan aksebilitas anak dalam proses pembangunan yang berjalan masih sangat terbatas dan tidak jarang mendapatkan perlakuan yang tidak adil dan timpang dari penduduk dewasa pada umumnya. Dalam kenyataannya dapat diidentifikasi berbagai situasi dan kondisi anak di kota padang. ${ }^{12}$

Dalam perspektif Undang-Undang Perlindungan Anak, Pasal 1 ayat (1) serta dikaitkan dengan teori perlindungan khusus anak, bahwa anak yang belum berusia 18 tahun termasuk anak yang masih dalam perlindungan, mereka tidak boleh menjadi tulang punggung ekonomi keluarga. Anak-anak hanya boleh berada di tiga tempat, yakni rumah, sekolah dan tempat mereka bermain saja. Apapun alasannya mempekerjakan anak di bawah umur merupakan perbuatan yang melanggar Undang-Undang Perlindungan Anak. ${ }^{13}$ Dengan bekerjanya anak-anak seolah-olah orang tua merasa beruntung padahal sebaliknya karena dampak yang ditimbulkan dari anak bekerja di bawah umur sangat banyak antara lain pertumbuhan fisik anak tersebut bisa terhambat, demikian juga pertumbuhan emosional dan pertumbuhan sosial serta moral.

Para orang tua yang memiliki anak di bawah umur namun tidak mampu menyekolahkan anak-anak mereka dikarenakan faktor ekonomi, sebaiknya mengkaji kembali keuntungan serta kerugian jika mereka mempekerjakan anak mereka pada tempat yang memiliki kondisi kerja yang tidak sesuai untuk anak di bawah umur. Para orang tua seharusnya menyadari bahwa dengan

12 BPMPKB, Laporan Pelaksanaan Kota Padang Sebagai Kota Layak Anak Tahun 2014, Badan Pemberdayaan Masyarakat, Perempuan dan Keluarga Berencana, Padang, 2014, hlm., 6.

13 Basri, Arif Roohman dan Yahya Ahmad Zein, Pengaruh Child Abuse Terhadap Regulasi Penetapan Tarakan Sebagai Kota Layak Anak, Jurnal Perspektif, Volume XVIII, Nomor 1, 26, 2013. 
mempekerjakan anak-anak mereka, berarti para orang tua telah mengorbankan kebebasan serta hak-hak anak. ${ }^{14}$

Untuk masyarakat pada umumnya, sebagai solidaritas yang tinggi terhadap warga lain di sekitar tempat tinggalnya, hendaknya masyarakat yang secara ekonomi lebih mampu daripada masyarakat yang lainnya, memberikan bantuan baik itu berupa modal usaha maupun dengan menjadi orang tua asuh bagi anakanak dari keluarga yang kurang mampu agar mereka dapat bersekolah. Penulis akan mencoba menyajikan bagaimana pelaksanaan perlindungan hukum dan upaya yang dilaksanakan oleh pemerintah Kota Padang, terhadap perlindungan khusus anak yang dieksploitasi secara ekonomi, yaitu melalui Dinas Sosial Tenaga Kerja (Dinsosnaker) Padang dan BPMKBP Kota Padang.

Menurut MM. Dt. Bandaro, Dinsosnaker Padang selalu berusaha untuk memberantas anak yang dieksploitasi secara ekonomi. Hal ini bisa dilhat dari beberapa upaya yang dilakukan oleh Dinsosnaker Padang, antara lain: ${ }^{15}$

1) Dinsosnaker Padang selalu berkoodinasi dengan Kementerian Sosial, antara lain bersinergi di dalam melaksanakan tugas-tugasnya dengan komitmen kementerian sosial, yaitu: a) Perlindungan Anak; ${ }^{16}$ b) Perlindungan Khusus; ${ }^{17}$ c) Usaha Penyantunan Anak Terlantar; ${ }^{18}$ d) Pelayanan Integratif (untuk anak);19

14 Andriyani Mustika Nuwijayanti, Eksploitasi Anak: Perlindungan Hukum Anak Jalanan Dalam Perspektif Hukum Pidana Di Daerah Yogyakarta, Jurnal Jurisprudence, Volume 1, Nomor 1, 208, 2012.

15 MM. Dt. Bandaro, Kepala Bidang Pelayanan dan Rehabilitasi Sosial Dinas Sosial dan Tenaga Kerja Kota Padang, wawancara dilakukan pada tanggal 2 November 2015.

16 Segala kegiatan untuk menjamin dan melindungi anak dan hak-haknya agar dapat hidup, tumbuh, berkembang, dan berpartisipasi, secara optimal sesuai dengan harkat dan martabat kemanusiaan serta mendapat perlindungan dari kekerasan dan diskriminasi

17 Perlindungan yang diberikan kepada anak dalam situasi darurat, anak yang berhadapan hukum, anak dari kelompok minoritas dan terisolasi, anak yang dieksploitasi secara ekonomi dan atau seksual, anak yang diperdagangkan, anak yang menjadi korban penyalahgunaan narkotika, alkohol, psikotropika, dan zat adiktif lainnya (napza), anak korban penculikan, penjualan, perdagangan, anak korban kekerasan baik fisik, dan/atau mental, anak yang menyandang cacat dan anak korban perlakuan salah dan penelantaran.

18 Usaha bimbingan dan pemeliharaan terhadap anak terlantar yang antara lain diselenggarakan melalui usaha pengangkatan anak sebagai upaya terakhir dalam usaha kesejahteraan anak.

19 Pelayanan yang melibatkan berbagai pihak yang memiliki kompetensi dalam upaya optimalisasi proses tumbuh kembang anak dan pengembangan fungsi kelembagaan. 
e) Pelayanan Kesejahteraan Sosial; ${ }^{20}$ f) Pelayanan Sosial;21 g) Pelayanan Sosial Anak Jalanan;22 h) Pelayanan Sosial Anak Terlantar. ${ }^{23}$

2) Dinsosnaker Padang melakukan razia dengan petugas Pamong Praja Kota Padang. Melakukan razia dengan Pamong Praja Kota Padang selalu dilakukan oleh Dinsosnaker Padang untuk meminimalisir anak yang dieksploitasi secara ekonomi, ini bisa dilihat dari tertangkapnya anak yang mengamen dan mengemis di lampu merah, pertokoan, taman-taman dan tempat umum lainnya. Terhadap hal ini Dinsosnaker Padang melakukan: a) Anak jalanan yang tertangkap dan masih berstatus anak sekolah, maka akan diberikan surat perjanjian dengan Dinsosnaker Padang, hal ini dilaksanakan agar tidak mengulangi perbuatannya dan mengutamakan sekolah; b) Anak jalan yang tertangkap dan berdomisili di luar Kota Padang, akan dikembalikan ke daerah asalnya dan dibuat surat perjanjian, hal ini dilakukan agar menimbulkan efek jera, sehingga anak tidak melakukan perbuatannya kembali; c) Anak yang tertangkap ternyata memiliki sistem terorganisir, maka pihak Dinsosnaker Padang akan bekerjasama dengan pihak Kepolisian Resort Kota Padang untuk mengungkapnya dan memberikannya hukuman sesuai dengan aturan yang berlaku. Orang tua yang menyuruh anak untuk mengamen atau mengemis, akan diberi nasehat dan diberi peringatan oleh Dinsosnaker Padang; d) Jika anak yang tertangkap tidak punya orang tua, dan daerah asalnya tidak jelas, maka anak tersebut akan dititipkan di Rumah Perlindungan Sosial Anak.

20 Serangkaian kegiatan pelayananyang diberikan terhadap individu, keluarga maupun masyarakat yang membutuhkan atau mengalami permasalahan sosial baik yang bersifat pencegahan, pengembangan,maupun rehabilitasi guna mengatasi permasalahan yang dihadapi dan/atau memenuhi kebutuhan secara memadai sehingga mereka mampu menjalankan fungsi sosialnya secara memadai (Kepmensos No. 10/Huk/2007).

21 Pelayanan yang ditujukan untuk membantu Penyandang Masalah Kesejahteraan Sosial dalam mengembalikan dan mengembangkan fungsi sosialnya.

22 Suatu proses pemberian pelayanan, perlindungan, pemulihan dan pemeliharaan taraf kesejahteraan sosial bagi anak jalanan agar memperoleh hak-hak dasarnya yaitu kelangsungan hidup, tumbuh kembang, perlindungan maupun partisipasi.

23 Proses atau serangkaian kegiatan yang dilakukan secara terorganisir, sistematis dan profesional terhadap anak terlantar guna terpenuhinya seoptimal mungkin hak anak untuk kelangsungan hidup, tumbuh kembang, perlindungan dan partisipasi. 
3) Dinsosnaker Padang melakukan kerja sama dengan Lembaga Swadaya Masyarakat. Dinsosnaker Padang juga menjalin kerjasama dengan Lembaga Swadaya Masyarakat ataupun aktivis-aktivis yang prihatin terhadap perlindungan anak khusus dieksploitasi secara ekonomi. Dinsosnaker Padang melakukan kerjasama antara lain dengan: a) Lembaga Swadaya Masyarakat Suci Hati; b) Lembaga Swadaya Masyarakat Cimpago dan c) Beberapa aktivis pemerhati anak.

Selain upaya di atas, Dinsosnaker Padang juga melakukan upaya lain yang mendukung perlindungan khusus terhadap anak yang dieksploitasi secara ekonomi ini, antara lain:

1) Anak yang tertangkap diberikan pelatihan oleh Dinsosnaker Padang. Tahun 2011-2014, Dinsosnaker Padang melalui dana APBD Kota Padang mengalokasikan dana untuk pelatihan keterampilan service hand phone bagi anak jalanan sejumlah 15 orang di rumah Perlindungan Sosial Anak (RPSA); ${ }^{24}$ tahun 2012, Dinsosnaker melakukan pelatihan keterampilan Montir Sepeda Motor bagi anak jalanan sebanyak 20 orang; 25 tahun 2013, melakukan pelatihan keterampilan Montir Sepeda Motor bagi anak jalanan sebanyak 15 orang; ${ }^{26}$ dan tahun 2014, melakuan pelatihan keterampilan service hand phone bagi anak jalanan sejumlah 15 orang. ${ }^{27}$

2) Kota Padang menyediakan Lembaga Penyelengaraan Kesejahteraan Sosial Anak Berhadapan Dengan Hukum (LPKS ABH). LPKS ABH ini difokuskan terhadap 16 (enam belas) Penyandang Kejahatan Sosial. Tempat ini disediakan oleh Kota Padang dengan bekerjasama dengan Kementerian Sosial.

24 Dinas Sosial Dan Tenaga Kerja Kota Padang, Laporan Pelatihan Service Hand Phone Bagi Anak Jalanan Kegiatan Pelatihan Keterampilan Dan Praktek Belajar Kerja Anak Jalanan Di Rumah Perlindungan Sosial Anak, Dinas Sosial Dan Tenaga Kerja Kota Padang, Padang, 2011, hlm., 1-5.

25 Dinas Sosial Dan Tenaga Kerja Kota Padang, Laporan Pelatihan Keterampilan Montir Sepeda Motor Bagi Anak Jalanan Kegiatan Pelatihan Keterampilan Dan Praktek Belajar Kerja Anak Jalanan Di Rumah Perlindungan Sosial Anak, Dinas Sosial Dan Tenaga Kerja Kota Padang, Padang, 2012, hlm., 1-4.

26 Id.

27 Supra no. 24. 
3) Kota Padang menyiapkan Kawasan Desa Kumenanti. Kawasan Desa Kumenanti ini diharapkan menjadi tempat yang berfungsi untuk mengatasi anak-anak yang tereksploitasi secara ekonomi. Kawasan Desa Kumenanti ini adalah sebuah program rumah layak yang diberikan kepada anak jalanan, gelandangan dan pengamen, serta pegemis. Anak-anak ini dibekali dan dididik serta diberikan keterampilan, sehingga nanti apabila kembali ke daerah asal mereka maka anak-anak akan bisa mempergunakan keahliannya tadi untuk mendapatkan uang, sehingga tidak kembali menjadi anak jalanan, gelandangan dan pengamen, serta pengemis.

4) Pembinaan Anak Jalanan, Gelandangan Dan Pengamen, Serta Pengemis Secara Langsung Ke daerahnya. Dinsosnaker Padang bersama Tenaga Kesejahteraan Sosial Kecamatan Pekerja Sosial Masyarakat (TKSK PSM) Kota Padang, akan turun langsung, kemudian memberikan pengarahan, nasehat serta pelatihanpelatihan keahlian berdasarkan bakat dan minat, yang nantinya berguna bagi anak-anak tersebut, sehingga mengurungkan niatnya untuk kembali menjadi anak jalanan, gelandangan dan pengamen, serta pengemis.

Badan Pemberdayaan Masyarakat, Perempuan dan Keluarga Berencana (BPMPKB) kota Padang, menurut Zunimar selalu berusaha untuk memberantas anak yang dieksploitasi secara ekonomi. Hal ini bisa dilihat dari beberapa upaya yang dilakukan oleh BPMPKB Kota Padang, antara lain:28

1. Selain pendekatan terpadu demi perlindungan khusus anak dieksploitasi secara ekonomi, adanya pendekatan bottom-up yang akomodatif terhadap aspirasi dari "bawah", dengan benar-benar membangun pilar keterbukaan, tranpasransi, membuka akses terhadap informasi, dan mengembangkan manajemen yang berbasis masyarakat madani (civil society based management) dalam pembangunan responsif anak.

2. Adanya strategi dengan mempersiapkan Model Kecamatan dan Kelurahan Ramah Anak yang pada tahun 2014, ini dilanjutkan dengan penetapan Pilot

28 Zulnimar, Staf Badan Pemberdayaan Masyarakat, Perempuan dan Keluarga Berencana (BPMPKB) Kota Padang, wawancara dilakukan pada tanggal 2 November 2015. 
Project kecamatan/kelurahan ramah anak pada 8 (delapan) kelurahan di 8 (delapan) kecamatan di Kota Padang.

3. Melakukan Sosialisasi Perlindungan Khusus eksploitasi secara ekonomi bagi anak di 11 (sebelas) Kecamatan. Dengan jumlah 104 kelurahan dari 11 (sebelas) Kecamatan maka BPMPKB Kota Padang memilih kelurahan-kelurahan yang akan diberikan sosialisai mengenai perlindungan khusus terhadap anak dieksploitasi secara ekonomi. Dimana sosialisasi ini telah dilaksanakan pada tahun 2013, tahun 2014 sampai dengan tahun 2015.

4. BPMPKB Kota Padang melakukan kerjasama dalam pemberian perlindungan khusus dieksploitasi secara ekonomi bagi anak dengan Lembaga Pemerintahan, Lembaga Swadaya Masyarakat serta beberapa aktivis yang peduli dengan perlindungan anak. Antara lain yaitu: a) Ruang Anak Dunia (RUANDA) Foundation; b) Dinas Kebersihan atau Pertamanan; c) BAPEDALDA; d) Dinas Kesehatan; e) Lembaga Perlindungan Anak (LPA); dan f) Komnas Perlindungan Anak.

5. BPMPKB Kota Padang mendapat dukungan anggaran terhadap perlindungan anak. Dukungan anggaran ini juga diperhatikan oleh organisasi atau lembaga peduli anak di Kota Padang yang melaksanakan beberapa kegiatan di lingkungannya dengan sasara utama anak. ${ }^{29}$

6. Membentuk Forum Anak. Forum Anak ini disediakan untuk anak yang berumur dari 1 tahun sampai dengan 18 tahun. ${ }^{30}$

29 Selain itu Pemerintah Kota Padang dalam mengembangkan kebijakan yang ramah anak selama ini juga mendapat dukungan dari Pemerintah Pusat, yakni Kementerian Pemberdayaan Perempuan Republik Indonesia melalui bantuan dana stimulasi daerah program Kesejahteraan dan Perlindungan Anak mulai tahun 2008, tahun 2009, tahun 2010, sampai dengan tahun 2011. Sedangkan dukungan anggaran dalam rangka pengembangan Kota Layak Anak yang dilaksanakan oleh SKPD-SKPD pada tahun 2014 Rp. 213.274.990.00,- dan di tahun 2015 Rp. 427.233.847.000,-.

30 Pembentukan Forum Anak ini agar dapat menampung aspirasi dan menyalurkan kreativitaskreativitas anak. Diharapkan Forum Anak ini bisa hadir disetiap kecamatan, atau bahkan kedepannya bisa hadir disetiap kelurahan di Kota Padang. Forum Anak ini sudah dicanangkan sejak tahun 2013 sampai dengan sekarang, dibawah komando Kementerian Pemberdayaan Perempuan Republik Indonesia. 
7. BPMPKB Kota Padang berencana membuat budaya yang mulai luntur, dihidupkan kembali, yaitu budaya tegur sapa. BPMPKB Kota Padang menilai nilai-nilai dan budaya semakin luntur terutama di Kota Padang, sehingga dengan mencanangkan budaya tegur sapa ini, akan membuat perlindungan anak semakin terwujud.

8. BPMPKB Kota Padang berencana menghidupkan kembali "Maghrib Mengaji". Hal ini dilakukan BPMPKB Kota Padang agar anak-anak setelah mendengar adzan maghrib, bisa lansung belajar mengaji dan tidak menyia-nyiakan waktunya dengan waktu yang tidak berguna, atau malah menggunakan waktu dengan bentuk-bentuk yang negatif.

Akibat dari eksploitasi anak di bidang ekonomi menurut Zunimar, berdampak serius terhadap anak antara lain: a) Hilangnya waktu bermain anak; b) Hilangnya kreativitas anak; c) Hilangnya sosialisasi anak terhadap teman sebayanya; d) Hilangnya waktu pendidikan anak; e) Berkurangnya nilai-nilai agama anak; f) Berkurangnya nilai sopan santun, budaya, dan budi pekerti; g) Berkurangnya ketertarikan anak akan dunia bermain; h) Anak berbicara dengan kasar; i) Anak menjadi liar dan terlalu dini mengetahui kehidupan dewasa dibandingkan anak seumurannya. ${ }^{31}$

Senada dengan hal diatas, menurut MM. Dt. Bandaro, eksploitasi anak di bidang ekonomi berdampak terhadap: 32

a) Anak kehilangan haknya untuk belajar. Sebagian besar anak jalanan adalah anak-anak yang putus sekolah dan bahkan tidak pernah merasakan bangku pendidikan.

b) Perilaku anak banyak yang menyimpang. Hidup di jalanan bukanlah hal mudah terlebih bagi anak di bawah umur. Mereka harus berjuang mencari uang dan besar kemungkinan terpengaruh hal-hal buruk, seperti merokok di usia anakanak, berbahasa kasar, terkadang bertengkar dengan anak-anak lainnya, dan sebagainya.

31 Supra no. 6.

32 Supra no. 15. 
c) Anak kekurangan kasih sayang. Hal ini juga merupakan faktor penyebab eksploitasi anak. Mereka dipaksa bekerja dan lebih banyak menghabiskan waktunya di jalanan mencari uang daripada merasakan kasih sayang dari orang tuanya.

\section{Kendala Pemerintah Kota Padang Dalam Memenuhi Perlindungan Anak}

Adapun secara umum permasalahan, tantangan dan hambatan yang umumnya berada di level nasional, antara lain:33 1) Norma, nilai dan sistem kepercayaan yang menjadikan anak rentan terhadap ketidakadilan dan pelanggaran Hak Asasi Manusia; 2) Masih adanya beberapa kebijakan yang diskriminatif dan patriaki. Selama ini kebijakan dan program yang ditujukan untuk anak masih bersifat variatif dan seringkali belum menjadi prioritas pembangunan; 3) Program-program pembangunan yang selama ini dilaksanakan secara lintas sektor, sektoral maupun kerjasama lintas organisasi non pemerintah masih bersifat parsial serta belum dilakukan secara menyeluruh dan terpadu; 4) Konvensi-konvensi Internasional dalam kaitan hak-hak anak yang sudah diratifikasi, belum diharmonisasikan ke dalam hukum nasional, regulasi regional bahkan menguasai lokal; 5) Globalisasi dan percepatan teknologi informasi, kemudahan mengakses diberbagai belahan dunia ternyata sangat memberikan peluang operasionalisasi kriminilitas terhadap anak seperti trafficking; dan 6) Permintaan pasar akan anak yang diperdagangkan terus meningkat oleh karena daya beli yang meningkat, lemahnya moral dan adanya asumsi bahwa anak-anak yang masih bersih dari segala penyakit, yang kemudian membuat orang dewasa tergiur untuk membisniskan anak-anak untuk mendapatkan keuntungan.

Selain hal di atas, berdasarkan penelitian yang telah penulis lakukan terdapat beberapa kendala di dalam pemenuhan perlindungan khusus terhadap anak yang dieksploitasi secara ekonomi, antara lain: ${ }^{34}$

\footnotetext{
33 BPMPKB, Laporan Pelaksanaan Kota Padang Sebagai Kota Layak Anak Tahun 2013, Badan Pemberdayaan Masyarakat, Perempuan dan Keluarga Berencana, Padang, 2013, hlm., 13.

34 Supra no. 6.
} 
1) Sifat anak yang keras kepala, menjadi salah satu hal penting yang susah untuk dibina, di mana hal ini membuat perlindungan khusus terhadap anak yang dieksploitasi secara ekonomi tidak terpenuhi. Karena setelah anak dibina dan dibimbing, namun karena sifatnya yang keras, si anak bisa kembali ke jalanan kembali.

2) Keluarga menjadi faktor penting terhadap perlindungan khusus terhadap anak yang dieksploitasi secara ekonomi. Karena jika keluarga terutama orang tua tegas terhadap anak, maka anak tidak akan terekspoitasi secara ekonomi. Orang tua fokus terhadap perlindungan dan pemenuhan-pemenuhan hak anak, sehingga tidak menyuruh anaknya untuk menjadi anak jalanan, pengemis atapun pengamen. Seharusnya keluarga lebih memahami dan mengerti bahwa anak bukanlah milik pribadi karena pada dasarnya setiap anak adalah sebuah pribadi yang utuh yang juga memiliki hak sebagaimana individu lainnya, sehingga anak tidak dapat dijadikan tumpuan amarah atas semua permasalahan yang dialami orangtua (Domestic Based Violence). Serta lebih berhati-hati dan memberikan perhatian serta menjaga anak-anak dari kemungkinan menjadi korban kekerasan yang dilakukan oleh orang-orang di sekitar kita (Community Based Violence).

3) Semakin lunturnya nilai-nilai agama dari seorang anak, keluarga dan masyarakat, maka anak akan mudah untuk terpengaruh dalam hal-hal negatif, hal ini tidak telepas dari eksploitasi anak dari sisi ekonomi. Jika nilai-nilai agama tadi diayomi, tidak akan terjadi eksploitasi anak dari sisi ekonomi. Karena setiap agama apapun tidak pernah mengajarkan untuk mengeksploitasi anak dari sisi ekonomi, agama menyarankan untuk melindungi dan memenuhi hak-hak anak.

4) Pendidikan. Pendidikan menjadi salah satu faktor penting di dalam pemenuhan perlindungan khusus terhadap anak yang dieksploitasi secara ekonomi. Jika setiap orang tua, masyarakat dan anak dibekali pendidikan yang cukup, makan 
eksploitasi anak ini tidak akan terjadi. Karena pendidikan juga mengajarkan bahwa anak harus dilindungi, dan tidak boleh dieksploitasi secara ekonomi.

5) Lingkungan tempat tinggal anak tidak mendukung agar anak mendapat perlindungan khusus tersebut. Bahkan lingkungan tempat tinggal, mendorong anak ke dalam pergaulan-pergaulan negatif, sehingga anak turun ke jalan menjadi pengamen dan pengemis. Seharusnya masyarakat lebih peka dan tidak menutup mata terhadap keadaan sekitar sehingga apabila terjadi kekerasan terhadap anak di lingkungan sekitar, penanganannya dapat lebih cepat guna menghindari kemungkinan yang lebih buruk pada anak yang bersangkutan. Aparat hukum seharusnya dapat lebih peka pada setiap proses penanganan perkara anak baik dalam hal anak sebagai korban tindak pidana maupun anak sebagai pelaku dengan mengedepankan prinsip demi kepentingan terbaik bagi anak (the best interest of the child).

6) Masalah ekonomi merupakan faktor pendukung yang membuat anak turun ke jalan. Demi memenuhi kebutuhan hidupnya, anak rela menghabiskan waktu yang seharusnya digunakan untuk bersekolah dan bermain diganti untuk mencari uang, demi untuk menyambung kehidupannya dan memenuhi kehidupan keluarganya. Selain itu ada juga beberapa oknum yang benar-benar mengeksploitasi anak untuk kepentingan ekonomi untuk kepentingannya semata. Terhadap hal ini pemerintah harus benar-benar bersinergi dengan masyarakat untuk memberantas hal ini.

7) Pergeseran budaya menjadikan anak kurang mengenal kehidupan yang baik. Pergeseran budaya ini menjadi hal penting karena budaya yang hidup di negara kita, tidak mengajarkan untuk mengeksploitasi anak secara ekonomi.

8) Fasilitas Penampungan Anak yang kurang menjadi kendala tersendiri dan cukup klasik. Hal ini selalu terjadi karena kurangnya fasilitas yang diberikan oleh pemerintah Kota Padang. Seharusnya fasilitas penampungan anak yang kurang segera dibenahi, karena faktanya sekarang jumlah anak cukup banyak di tempat penampungan anak. Seharusnya hal ini segera disikapi dengan benar, 
pemerintah di dalam Anggaran Pendapatan Belanja Daerah (APBD) 2016 harus memprioritaskan pemenuhan fasilitas tempat penampungan anak tersebut.

9) Sumber daya manusia baik dari Dinsosnaker Padang ataupun Badan Pemberdayaan Masyarakat, Perempuan dan Keluarga Berencana (BPMPKB) kota Padang di dalam melaksanakan pemenuhan perlindungan khusus anak yang dieksploitasi secara ekonomi ini sangatlah minim. Sehingga tidak membuat maksimal kinerja dari para stakeholder tersebut. Atas hal ini seharusnya pemerintah harus memperhatikannya secara khusus. Mengingat anak merupakan penerus dari bangsa dan negara ini, terutama penerus dari Kota Padang.

10)Dana yang kurang memadai ini merupakan persoalan klasik yang selalu muncul tiap tahun. Kota Padang harus benar-benar serius untuk menyiapkan dan mengelola dana perlindungan khusus untuk mengatasi hal ini. Bahkan jika dirasa perlu mendatangkan tenaga ahli dalam mengelola hal ini, sehingga persoalan yang sama tidak muncul setiap tahunnya.

\section{Konsep Dan Gagasan Kedepan Di dalam Menata Pemenuhan Perlindungan Anak Di Kota Padang}

Melihat masih banyaknya anak-anak yang terlantar di Kota Padang, terutama yang tereksploitasi ekonomi, ada baiknya pemerintah kota padang membentuk konsep serta gagasan perlindungan anak yang baik, sehingga perwujudan dari kota layak anak yang selalu disuarakan oleh pemerintah dapat tercapai semaksimal mungkin.

Berdasarkan hasil penelitian Otong Rosadi di Provinsi Sumatera Barat, masalah anak setelah krisis ekonomi dan krisis multidimensional melanda bangsa ini. Hampir semua bentuk pelanggaran hak anak dan masalah kesejahteraan anak terdapat di daerah-daerah bagian Provinsi Sumatera Barat, termasuk Kota 
Padang. Data lapangan menunjukkan masalah anak terlantar dan anak jalanan (eksploitasi ekonomi) menempati porsi yang paling besar ${ }^{35}$.

Penulis mencoba menawarkan beberapa konsep dalam menata perlindungan anak di Kota Padang, sehingga perlindungan ini berkelanjutan dan tidak mati di tempat atau mati di dalam kajian teori saja. Antara lain upaya yang dapat dilakukan oleh Pemerintah Kota Padang adalah:

a. Pengayoman, terkait hal ini dapat diartikan bahwa pihak yang dilindungi dapat merasa aman dalam perlindungan tersebut. Kepentingan dan hak asasinya terjamin dan tidak dirugikan dan diusahakan dikembangkan, sehingga dapat mencapai pertumbuhan fisik, mental dan sosial secara maksimal; yang melindungi harus merasa bahwa dirinya mendapat perlindungan dan jaminan dalam kegiatan perlindungan sebagai pemenuhan tugasnya, dan mendapat hak yang layak dari pemerintah dan masyarakat; 36

b. Usaha bersama kegiatan perlindungan adalah suatu kegiatan yang menjadi tanggung jawab bersama antara pihak-pihak yang dilindungi dan yang melindungi; harus ada saling pengertian antara mereka sebagai pihak-pihak yang bersangkutan agar mencapai hasil yang baik, ada interaksi antara kedua pihak; yang dilindungi harus diyakinkan bahwa ia ikut serta dalam kegiatan perlindungan anak ini dengan berusaha melindungi dirinya sendiri sesuai dengan kemampuannya; dan kegiatan perlindungan bukan monopoli seseorang atau badan/organisasi swasta maupun pemerintah; 37

c. Kepentingan bersama, dengan melindungi seorang anak berarti menghindari dari kesulitan yang mungkin menimpa/mengancam yang melindungi (orang tua, pemerintah) dibandingkan dengan apabila anak tidak dilindungi atau dilayani kepentingannya. Jadi penggunaan dana yang cukup besar tidak sia-sia;

\footnotetext{
Otong Rosadi, Hak Anak Bagian Dari HAM, Wildan Akademika, Bandung, 2004, hlm., 62-63. Emeliana Krisnawati, Apek Hukum Perlindungan Anak, CV. Utomo, Bandung, 2005, hlm., 44-45. Id.
} 
dan yang dilindungi jangan sampai menjadi korban dari yang melindungi dengan dalih untuk melindungi kepentingan pribadi; ${ }^{38}$

d. Unsur edukatif yaitu pemberian perlindungan harus bersifat edukatif dan membangun yang diarahkan kepada kemampuan untuk mengembangkan diri sehingga akan dapat bermanfaat untuk pembangunan nasional; pemberian perlindungan jangan sampai menjurus pada pemuasan diri, yaitu rasa lebih berjasa dari pada yang dilindungi. ${ }^{39}$

Bagi anak yang dieksploitasi secara ekonomi, gagasan perlindungan khusus anak oleh pemerintah daerah dapat dilakukan dengan cara-cara konvensional, dimana hal ini antara lain sebagai berikut:

a. penyebarluasan atau sosialisasi ketentuan peraturan perundang-undangan berkaitan dengan perlindungan anak yang dieksploitasi secara ekonomi;

b. melakukan pemantauan terhadap perlindungan anak;

c. masyarakat secara aktif memberikan laporan terhadap perlindungan anak, atau dengan kata lain menumbuhkembangkan sifat lapor kepada masyarakat, jika melihat ada hak anak yang dilanggar;

d. pemerintah memberikan sanksi tegas terhadap pelanggaran perlindungan anak, sehingga ada efek jera bagi para pelaku ataupun masyarakat yang ingin melanggar ketentuan perlindungan anak;

e. melibatkan berbagai instansi pemerintahan, perusahaan, serikat pekerja, lembaga swadaya masyarakat dalam perlindungan anak.

Selain itu menurut penulis, untuk perlindungan khusus anak terutama dari eksploitasi secara ekonomi, Pemerintah Kota Padang ataupun pemerintah daerah kota lain harus membuat regulasi khusus. Karena aturan ini sangat dibutuhkan, mengingat kebutuhan tenaga kerja di zaman modernisasi dan globalisasi.

Membuat regulasi terkait Perlindungan khusus anak yang tereksploitasi secara ekonomi, juga akan terkait dengan Undang-Undang lainnya, misalnya saja undang-undang HAM, Tenaga Kerja, Perlindungan Anak, dan Sistem Peradilan 
Anak. Maka dari itu perlindungan khusus anak yang tereksploitasi secara ekonomi harus dimulai dengan aturan dari Pemerintah Pusat, kemudian dengan acuan aturan itu, pemerintah daerah membuat aturan-aturan yang serupa juga.

Sehingga menurut penulis, dengan membuat kebijakan regulasi khusus anak yang tereksploitasi secara ekonomi, akan menjamin perlindungan anak yang berkelanjutan baik oleh pemerintah pusat secara umum dan pemerintah daerah secara khusus, karena pemerintah daerahlah yang mewakili pemerintah pusat bersentuhan lansung dengan anak dan kebutuhan-kebutuhan perlindungan anak.

\section{Penutup}

Penulis menyimpulkan bahwa anak-anak yang dieksploitasi secara ekonomi, telah dibina dan diberi pelatihan keterampilan oleh Dinsosnaker Padang dan BPMPKB Kota Padang. Sedangkan faktor-faktor yang menyebabkan tidak terpenuhinya pemenuhan hak perlindungan anak dieksploitasi secara ekonomi, karena lahir dari sifat anak, keluarga, nilai agama yang luntur, pendidikan, lingkungan masyarakat, masalah ekonomi, pergeseran budaya, sumber daya manusia, dan dana yang kurang memadai. Kedepannya menurut penulis Kota Padang harus memperhatikan kendala-kendala klasik ini, agar pemenuhan perlindungan hak anak ini dapat terwujud dengan nyata. Selain itu masyarakat dan keluarga anak, juga harus lebih diberi pemahaman mengenai perlindungan anak. Agar semua lapisan masyarakat mengerti, arti penting perlindungan anak dieksploitasi secara ekonomi. Demi terwujudnya perlindungan khusus anak yang tereksploitasi secara ekonomi, maka perlu dibuat konsep-konsep perlindungan khusus anak yang berkelanjutan, serta membuat gagasan-gagasan perlindungan khusus anak yang tereksploitasi secara ekonomi oleh pemerintah pusat dan pemerintah daerah, demi menjamin perlindungan anak yang bukan hanya dalam teori saja, tetapi juga dalam aplikasi kehidupan. 


\section{Daftar Pustaka}

\section{Buku:}

Arif Gosita, Masalah Perlindungan Anak, PT Bhuana Ilmu Populer, Jakarta, 2004.

BPMPKB, Laporan Pelaksanaan Kota Padang Sebagai Kota Layak Anak Tahun 2013, Badan Pemberdayaan Masyarakat, Perempuan dan Keluarga Berencana, Padang, 2013.

, Laporan Pelaksanaan Kota Padang Sebagai Kota Layak Anak Tahun 2014, Badan Pemberdayaan Masyarakat, Perempuan dan Keluarga Berencana, Padang, 2014.

Laporan Pelaksanaan Kota Padang Sebagai Kota Layak Anak Tahun 2015, Badan Pemberdayaan Masyarakat, Perempuan dan Keluarga Berencana, Padang, 2015.

Dinsosnaker Padang, Laporan Pelatihan Service Hand Phone Bagi Anak Jalanan Kegiatan Pelatihan Keterampilan Dan Praktek Belajar Kerja Anak Jalanan Di Rumah Perlindungan Sosial Anak, Dinsosnaker Padang, Padang, 2011. , Laporan Pelatihan Keterampilan Montir Sepeda Motor Bagi Anak Jalanan Kegiatan Pelatihan Keterampilan Dan Praktek Belajar Kerja Anak Jalanan Di Rumah Perlindungan Sosial Anak, Dinsosnaker Padang, Padang, 2012.

Pelatihan Keterampilan Montir Sepeda Motor Bagi Anak Jalanan Kegiatan Pelatihan Keterampilan Dan Praktek Belajar Kerja Anak Jalanan Di Rumah Perlindungan Sosial Anak, Dinsosnaker Padang, Padang, 2013.

_. Laporan Pelatihan Service Hand Phone Bagi Anak Jalanan Kegiatan Pelatihan Keterampilan Dan Praktek Belajar Kerja Anak Jalanan Di Rumah Perlindungan Sosial Anak, Dinsosnaker Padang, Padang, 2014.

Emeliana Krisnawati, Apek Hukum Perlindungan Anak, CV. Utomo, Bandung, 2005.

H.R Abdussalam, Hukum Perlindungan Anak, Restu Agung, Jakarta, 2007.

Laurensius Arliman S, Komnas Ham dan Perlindungan Anak Pelaku Tindak Pidana, Deepublish, Jogjakarta, 2015.

Maidin Gultom, Perlindungan Hukum Terhadap Anak dan Perempuan, Refika Aditama, Bandung, 2012.

Otong Rosadi, Hak Anak Bagian Dari HAM, Wildan Akademika, Bandung, 2004.

Wagiati Soetodjo, Hukum Pidana Anak, Refika Aditama, Bandung, 2006.

\section{Jurnal}

Andriyani Mustika Nuwijayanti, Eksploitasi Anak: Perlindungan Hukum Anak Jalanan Dalam Perspektif Hukum Pidana Di Daerah Yogyakarta, Jurnal Jurisprudence, Volume 1, Nomor 1, 2012.

Astriani Rahman, Eksploitasi Orang Tua Terhadap Anak Dengan Mempekerjakan Sebagai Buruh, Jurnal Ilmu Hukum, Volume 8 Nomor 16, 2013.

Basri, Arif Roohman dan Yahya Ahmad Zein, Pengaruh Child Abuse Terhadap Regulasi Penetapan Tarakan Sebagai Kota Layak Anak, Jurnal Perspektif, Volume XVIII, Nomor 1, 2013. 
Iman Jauhari, Perbandingan Sistem Hukum Perlindungan Anak Antara Indonesia dan Malaysia, Jurnal Ilmu Syari'ah dan Hukum, Volume 57 Nomor 2, 2013.

Nur Hidayati, Perlindungan Anak Terhadap Kejahatan Kekerasan Seksual (Pedofilia), Ragam Jurnal Pengembangan Humaniora, Volume 14 Nomor 1, 2014.

Wiwik Afifah, Pertanggungjawaban Pidana Anak Konflik Hukum, Jurnal Ilmu Hukum, Volume 10 Nomor 19, 2014.

\section{Wawancara}

MM. Dt. Bandaro, Kepala Bidang Pelayanan dan Rehabilitasi Sosial Dinsosnaker Padang, wawancara dilakukan pada tanggal 2 November 2015.

Zulnimar, Staf Badan Pemberdayaan Masyarakat, Perempuan dan Keluarga Berencana (BPMPKB) Kota Padang, wawancara dilakukan pada tanggal 20 September 2015.

Staf Badan Pemberdayaan Masyarakat, Perempuan dan Keluarga

Berencana (BPMPKB) Kota Padang, wawancara dilakukan pada tanggal 2 November 2015. 